\title{
Land-Use Planning Guidelines for Optimal Coastal Environmental Management
}

\author{
Martin Lee Collin*, Abraham Jacob Melloul
}

Hydrological Service, Water Authority, Jerusalem, Israel.

Email: *mlcollin@netvision.net.il

Received January 28 ${ }^{\text {th }}, 2012$; revised February 23 ${ }^{\text {rd }}, 2012$; accepted March $17^{\text {th }}, 2012$

\begin{abstract}
The objective of this study is to weigh and recommend environmentally-optimal regional land-use planning guidelines for coastal regions. The present malaise is assessed, as regards inefficiencies, non-suitability, non-sustainability, enhancing factors of environmental degradation, and potentially destructive consequences of current land-use alteration. Desired situations and goals are considered, and means are proposed for bridging the gap between the present malaise and a desired situation, based on five key approaches developed by the authors. Specific examples of regional approaches are presented. Guidelines and operational measures for sound regional planning the authors have employed in similar circumstances are recommended.
\end{abstract}

Keywords: Land-Use Planning; Environmental Management; Malaise; Anthropogenic Pollution; Vulnerability Assessment; Monitoring; Urban-Rural Amenities; Maslow Pyramid

\section{Introduction-The Current Malaise}

Measuring the degree of success of land-use alteration solely on the basis of money and convenience characterizes the arrogant human quest to subdue and conquer Nature. The resultant malaise has degraded both the natural environment and the human spirit, reducing quality of life, quality and quantity of natural resources, and fulfillment of human needs [1] (Figure 1).

\subsection{Natural Origins of Malaise}

Natural parameters that partially contribute to the present malaise include erodible coastal lithology, a parameter which can lead to landslides. Where combined with low coastal profiles and slopes, such erodibility can lead to inundation of inland floodplains [2-4]. Additional natural parameters that can threaten coastal regions are waves and tidal activities, as well as proximity to active seismic zones, and volcanic activity. Seismic incidents can result in sudden sea level rise (SLR), placing coastal regions in danger from high tsunami waves, which can salinate coastal groundwater resources and permanently deteriorate coastal soils.

Ancillary effects of such events can include erosion as well as contamination of inland wells and ponds by the mixing of seawater and fresh water, leading to significant loss of fresh water [5,6] (Figure 1).

${ }^{*}$ Corresponding author.

\subsection{Anthropogenic Origins of Malaise}

\subsubsection{Fuel and Energy Usage: Climate Change and Sea Level Rise (SLR)}

In parallel to our world's soaring population increase, output of a wide variety of chemical emissions from employment of fossil fuels has vastly expanded. Earth's atmosphere has become polluted with particulates, aerosols, and significant amounts of such greenhouse gases as $\mathrm{CO}_{2}, \mathrm{~N}_{2} \mathrm{O}$, and $\mathrm{CH}_{4}$ [7-10].

Climate change due to green-house gasses could lead to increase in global temperatures, causing continental and polar glaciers to melt. Ancillary steric effects could increase off-shore water volume of oceans and seas resulting in an on-going SLR over just decades. Together, these results would have a significant adverse impact upon global seacoast environments [8,11-16]. Long-term coastal land-use planning has failed to take on-going sea level rise into account (Figure 1).

\subsubsection{Malaise Due to Over-Exploitation and Improper Use of Natural Resources}

As an example of improper use of resources, over-exploitation of groundwater has elicited seawater intrusion into coastal aquifers, salinating ambient groundwater [17-27]. Inland alteration in groundwater flow patterns by over-pumping has resulted in cones of depression, concentrating salinity and pollutants in the vadose zone (Figure 1) [28,29]. 


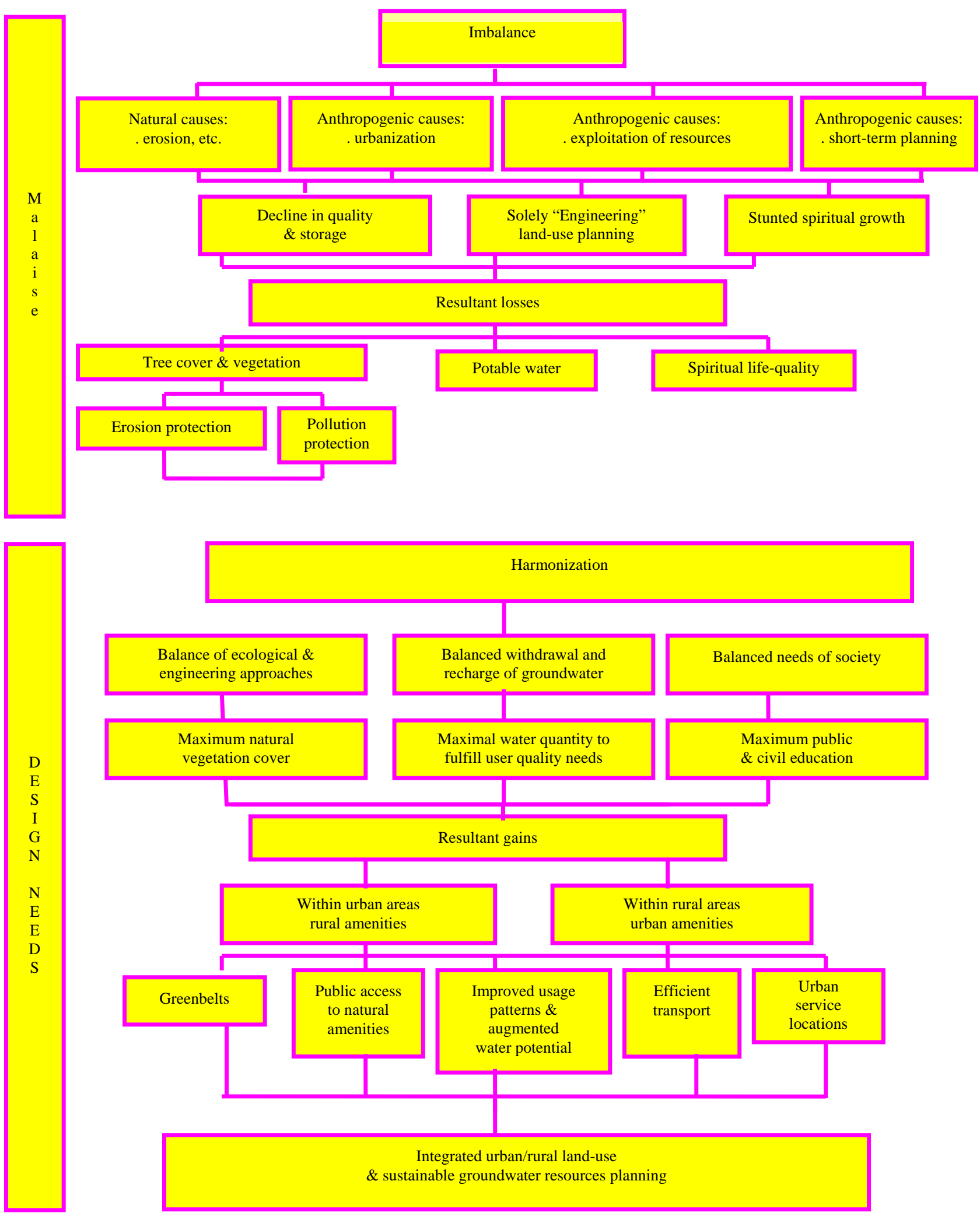

Figure 1. Harmonizing land-use planning with groundwater sustainability management (Collin and Melloul, 2003).

During periods of drought, malaise has resulted from short-sighted regional water management planning. By not financing integration of storm-drainage with sewage water treatment facilities, a significant amount of rain- 
water has been lost. Instead, storm-drainage has been allowed to drain, unutilized, to the sea.

Viewing Nature as a commodity, the "engineering" approach to land-use planning, sacrifices innate benefits Nature offers to human quality of life. Effective longterm planning should take the full range of human needs into account in order to maximize benefits, both for the regional community and its sustainable resources.

\subsubsection{Malaise Due to Reduction of Native Vegetative Land Cover and Soil Debasement}

\subsubsection{Deforestation}

Deforestation has resulted from intensive demand by populations for increased agricultural production (Figure 1). "Slash-and-burn" agriculture has laid waste to beautiful and ecologically-critical old-growth forest cover, in equatorial jungles such as Brazil's Amazon region or Indonesia, and in such northern forests as those of the northwestern US states of Washington and Oregon [30].

\subsubsection{Malaise Due to Wetland and Mangrove Destruction}

Destruction of naturally protective coastal vegetation, such as mangroves, which serve as hugely efficient buffers of highly erodible coastal lithologies, has augmented coastal instability. Long term, such changes intensify destructive effects of hurricanes and tsunamis [31].

\subsubsection{Malaise Due to Destruction of Physical and Chemical Soil Characteristics by Improper Agricultural Practices}

Improper agricultural activities have altered soil characteristics and polluted water resources and harmed natural fauna and flora with excessive amounts of fertilizers, pesticides, a surfeit of manure and chemicals, and minimally-treated effluents for irrigation (Figure 1). A soil's b-horizon is the critical soil zone from which most vegetation root-systems take up requisite nutrients. It is also the soil zone where colloidal clays and natural organic material accumulate [32,33]. Excessive tillage and ongoing non-rotated growth of such crops as cotton have altered the soil colloidal matter of the b horizon. Clays with high cation exchange capacity (CEC), such as montmorillonite and vermiculite, have been altered to clays having significantly lower CEC, absorption, and adsorption, thus offering lowered fertility for plant growth [19,34-37].

Trees, by bolstering soil structure, preserve colloidal clay and natural organic matter that fix needed chemicals for plants, lending the soil its innate fertility. The higher the exchange-capacity of these soil colloids the higher the resulting fertility of the soil. Root systems act as efficient filtering systems to remove contaminants from sur- face water percolating through the soil. Root systems also maintain the stability of soil under threat of erosion by drainage water during storm events. They thus minimize sediment contamination of nearby surface water [36].

\subsubsection{Malaise Due to Poorly-Planned Urbanization Vis-à-Vis Regional Environment}

Natural assets, historical treasures, and scenic beauty have been lightly sacrificed as dispensable commodities, the underlying standard being shortsighted self-interest [38]. The renowned landscape architect and urban planner, Ian McHarg noted that the spread of cities and their attendant utilities over the coastal landscape has encouraged growth of urban blight [38]. In many cities, rampant paving-over of the urban periphery to enable residential land-use has become the cause of devastating floods. As urban concretization inexorably shellacs the land surface's natural land cover and pollutes the air of urban regions, natural percolation of surface water has also been impeded, further restricting recharge of phreatic aquifers $[24,39,40]$. Concretization has contributed towards higher micro-climate temperatures in warmer seasons, wasting copious quantities of rainfall, draining unutilized into the sea [41].

Short-sighted urban planning and the "engineered" planning approach towards land-use alteration to further strictly pragmatic short-term economic objectives, has been measured solely in money and convenience, losing sight of the imaginative insights of landscape architecture [39]. In many urban regions natural amenities have been eradicated. This has resulted from inappropriate siting of industrial or commercial locations, as well as development of high-intensity residential areas lacking vegetation and spiritually-supportive human amenities. This has sharply reduced quality of life by degrading the quality of air and lowering the quantity of natural resources available for users, and impeded sustainable resource utilization (Figure 1) [42-44].

\subsection{Exemplary Regions Suffering Symptoms of Malaise}

Exemplary regions suffering symptoms of environmental malaise owing to natural and anthropogenic effects can be highlighted here.

\subsubsection{Coastal Areas of Israel}

Israel's coastal region, especially the Tel Aviv Metropolitan region and the Sharon region bordering it on the north, have witnessed a range of anthropogenic causes for environmental malaise.

1.3.1.1. The Tel Aviv Metropolitan Region's Waterfront Israel's coastal region can be exemplified by the Tel 
Aviv Metropolitan region and the Sharon region bordering it on the north. Both have witnessed to a range of anthropogenic causes for environmental malaise. These have included domestic and industrial effluent pollution that has seeped down to the rather shallow unconfined Coastal aquifer. Some of this pollution has involved untreated or insufficiently treated effluents used for agricultural irrigation. Another anthropogenic cause of environmental malaise has resulted from poorly planned land-use alteration, especially sites located along the waterfront, where private "development" has often precluded public access to beaches [23,45-47].

Inadequate municipal and regional planning guidelines for land-use alteration have frequently exhibited poor prioritization tied to random and uncoordinated regional planning. The result has been inadequate public access to the waterfront, environmental deterioration, and lack of any consideration and coordination with otherwise valuable natural coastal amenities [32,34]. These amenities include the marvelous seacoast, water resources, vegetation, and climate. No consideration was taken of a Maslow Pyramid model for ranking levels of importance for planning undertakings. No strategy was employed towards land-use alteration tied to natural constraints and amenities, as typifies the McHarg approach. Rather, a laissez faire lack of private and governmental coordination as regards land-use planning has precluded initiatives that might otherwise have enhanced the influence of natural amenities on the regional environment, while diminishing rather than augmenting the advantages the region's natural assets could have contributed to the environmental image of the region.

\subsubsection{Land-Use Planning in Israel's Sharon Region}

Directly to the north of the Tel Aviv Metropolitan Region, the Sharon Region could be considered the "breadbasket” of Israel. But its key natural asset, groundwater, has been significantly impacted by groundwater pollution, a major portion of which has resulted from use of untreated or improperly treated effluents applied to crops for agricultural irrigation [48]. Rampant pollution has been augmented by a lack of assessment of vulnerability and sensitivity regarding key regional natural resources, location and extent of regional pollution foci, and siting requisite monitoring networks [48].

\subsubsection{Selected Coastal Areas Elsewhere in the World}

Many global areas have suffered from a similar malaise as that in Israel, owing to lack of proper environmental planning. Pollution and inappropriate planning have had significant negative impact upon otherwise important resources [44].

\subsubsection{Chicago's Lake Michigan Shoreline}

At the beginning of the Twentieth Century, Chicago suf- fered from a malaise typical of most coastal cities [49]. The waterfront was dominated by port activity, railroads and railyards, industrial enterprises, and residential slums. The city had literally turned its back on its key geographic asset - the Lake Michigan coastline. Random and uncoordinated regional planning and initiatives, together with rampant environmental deterioration, turned the waterfront and the Chicago River inlet into cesspools of waste [49]. Chicago had just recovered from the catastrophic Chicago Fire of 1871. Inadequate public access to the waterfront, random and uncoordinated regional planning, and rampant environmental deterioration characterized the shoreline. As was the case of Chicago's lakefront, elsewhere in the world, poorly prioritized and inadequately coordinated planning with regional natural amenities remained a challenge for land-use initiatives.

\subsubsection{Baltimore's Harbor Shoreline}

In contrast to Chicago, which fronted on a linear shoreline [50], the Baltimore Metropolitan region developed along a labyrinthine coastline, centered in its Inner Harbor [51]. As of 1973, Baltimore's harbor and bay-front shoreline was its crucial regional asset. But this was inaccessible to its region's population. Baltimore Harbor functioned as a major port facility and industrial site. Random, uncoordinated land-use alteration by competitive developers, poorly integrated regional planning, and increasing environmental deterioration all contributed to an inner-city malaise. Regional urban land-use alteration was characterized by a lack of prioritization and coordination, lacking harmony between land-use alteration and natural terrain conditions. Building was carried out on erodible slopes and in flood plains frequently inundated by seasonal overflow. Key agricultural farmland and forest cover was eradicated. Minimal open space for recreational remained. This malaise contributed to a general sense of depression on the part of city and regional residents with their environment.

\subsubsection{Approaches to Soil Degradation in the US and China}

Deforestation and land-use contribution towards soil degradation are characteristic of various areas in the world [52,53].

Soil degradation, leading especially to desertification, characterizes large areas of the globe. This paper notes areas in the United States and China [34,37].

Contributory to this malaise have been uncoordinated agricultural land-use as well as minimal harmonization of such land-use with the natural amenities of the land and climate [52,53].

\section{The Desired Situation}

A set of key environmental and socio-economic concerns 
must be addressed in the course of land-use planning decision-making. When addressing these concerns, realistic targets should be set (Figure 1).

\subsection{Satisfactory Levels of Air Quality}

A wide suite of pollutants result from Industrial sources, vehicular traffic, and agriculture. Significant reduction of particulate emissions, smog-inducing aerosols, and such gases as $\mathrm{CO}_{2}, \mathrm{~N}_{2} \mathrm{O}$, and $\mathrm{CH}_{4}$ into the atmosphere could mitigate ambient climate change, consequent global warming, steric effects, and sea level rise [44]. Minimizing air pollution could reduce harmful impact upon global flora and fauna, lower medical costs to the world's human population, and raise the ambient quality of life. Such reduction could result once economically feasible alternative energy sources replace the burning of fossil fuels for power sources and vehicles.

\subsection{Satisfactory Levels of Water Quantity and Quality}

Water quality can be defined as the set of values of physical, chemical, and/or biological parameters of water as related to accepted, desired standards for any given category of use [54]. Quality of water suitable for human needs can vary widely; what is satisfactory for one purpose may not be for another. Usage-value of a given water quality for a particular category of use is the worth of a unit volume of water of that quality to a user in that category [54]. Thus, differing water quality standards must be strictly tailored to the requirements of domestic drinking, industrial, and agricultural usages [43].

Sustainable development must ideally maintain the equilibrium of the natural ecosystem. Minimal use of non-renewable sources could mitigate ambient environmental loss. "Mining" of such resources needs to be replaced by recycling. Altered usage patterns and input of new non-conventional water sources could be employed, as long as these do not themselves reduce the resulting usage-value of the ambient resources (Figure 1) [45,54]. Improved irrigation methods should be encouraged, decreasing net water loss by employing drip rather than sprinkler or canal irrigation. Maximally treated effluents applied as primary sources for agricultural irrigation could ensuring minimal negative impact to groundwater quality and integrity of soils, especially where significant percolation through shallow surface soil and unsaturated zone layers to unconfined phreatic aquifers can be expected.

\subsection{Satisfactory Groundwater Storage}

Water supply management planning should ideally take drought periods into account, during which rainfall depths are smaller than the minimal amount required for re- charge of a groundwater basin. A desired level of efficient capture of natural rainfall drainage, tied to sustainable usage, would enable proper levels of recharge. Efficiently capturing natural coastal rainfall drainage by integrating storm-drainage with current sewage water treatment systems would quickly repay start-up preparation costs by reducing costs for drinking water. By tying water tariff to water quality, groundwater reservoirs could then prove adequate for long-term utilization solely for drinking purposes (Figure 1) [55,56].

\subsection{Establishment and Enforcement of Pollution Parameter Standards}

Efficient and properly planned water resources management requires effective monitoring. Appropriate standards regarding potential pollution parameters form the basis for cost-effective monitoring networks that could satisfactorily protect surface and groundwater resources (Figure 1). Where such monitoring would indicate the need, water remediation and conservation measures could then be taken. Not all pollutant impact is readily reversible within a human time frame. Decision-making should then be based upon accurate registers of potential pollution sites, anticipating types and quantities of pollutants likely to impact the regional environment.

\subsection{Satisfactory Desalinization and Effluent Treatment}

Desalinization and effluent treatment can provide desirable operational means for water resource remediation. Desalinization of seawater and saline, brackish groundwater, import of fresh water from other sources, and use of properly treated effluents could prove ecologicallyeffective measures for maintaining sustainable water resources, especially during times of drought in arid regions. A key challenge to cost-effective desalinization is, of course, energy efficiency.

Irrigation of agricultural crops, especially those having lower sensitivity to salinity, with satisfactorily treated effluents could enable use of higher quality fresh water for drinking. Efficient irrigation methods, such as drip irrigation on arid and semiarid land, would need to be employed.

\subsection{Mitigation of Aquifer Salinization by Preventing Sea Level Rise (SLR)}

On-going sea level rise (SLR) can salinate coastal aquifers. To minimize climate change that could lead to glacial melting and consequent SLR, appropriate measures would need to be adopted by all nations [57].

\subsection{Planting and Maintaining Vegetation and Tree Cover}

Vegetation enhances soil fertility by retaining soil aera- 
tion and often returning needed nitrogen by means of rhizobic nitrogen-fixing bacteria symbiotically tied to the roots of legumes. Tree-cover and other vegetation filter the air, cleansing it of excess $\mathrm{CO}_{2}$ in return for added $\mathrm{O}_{2}$. Root systems protect soil from erosion. Especially along coastlines, vegetative cover should be enhanced [36].

Three approaches could encourage sound soil conservation and healthy vegetative land cover. Firstly, to retain long-term fertility of otherwise low-fertility soils, a Native American technique could be employed, plowing in charcoal, food refuse, and other solid waste to produce black, well-aerated, highly fertile, carbon-enriched soils that retain their fertility over extended periods of time [37]. Secondly, tree-cover and deeply-rooted soil- and sand-fixing plants and groundcover adapted to local environments, such as fescue, could serve as efficient anchors in areas where physiographic vulnerability of steepsloping sea-side cliffs and valley walls are prone to erosion. And finally, conservation advisors could encourage no-till farming, proper crop rotation, and use of humus and detritus for soil fertilization and aeration to protect and enhance fragile soil.

\subsection{Integrating Urban/Rural Land-Use}

A proper blend of urban and rural land-use could provide adequate rural amenities to urban areas and adequate urban amenities to rural areas. Urban areas could enjoy clean air and water, maintenance of maximal tree and ground vegetative cover, as well as maximal public access to natural amenities. Rural areas could enjoy efficient and rapid public transportation access to such urban amenities as employment and education complexes, cultural centers, and sports facilities [58].

In urban areas, local gardens and growth of vegetation on flat roof-tops should be encouraged. These could lower urban temperatures, maximize rainfall utilization, and provide a soothing natural visual environment for the inhabitants (see §3.2.2)

\subsection{Guarding of Floodplains}

Building in floodplains entails danger of significant potential loss to residents. Proper flood plain management could preclude such loss [51,59]. Stream or river floodplains are best employed for agriculture, wetlands, recreational parkland, etc. Land-use alteration in floodplains for the purposes of residential or commercial purposes should be discouraged. Proactive development of wetlands, especially mangroves could be critical for protecting the physical, chemical, and biological integrity of coastal regions, as well as serving as vital feeding and nesting areas for birds, fish, and amphibious fauna.

\section{Methodology_Five Tools for Bridging the Gap between the Current Malaise and the Desired Situation}

Tools the authors have employed in their work towards assessing key regional natural resources vulnerability and sensitivity include a lithological presentation of the study area (Figure 2), Composite DRASTIC model (Figure 3) [60], as well as registers of current pollution sites (POLLSITE) and recommended monitoring sites (MONET) [42]. The concept of Maslow's pyramid (Figure 4) [61, 62] has assisted them in prioritizing management steps, while land-use planning based upon natural amenities and constraints-Ian McHarg's approach [38], has assisted towards mitigating a considerable portion of malaise from which the region the authors have dealt with has recently suffered.

\subsection{Assessing the Current Situation}

Of the five key tools the authors have employed in their regional and environmental planning decision-making, three influence assessment of current situations, and two determine their approach to land-use planning. These tools have enabled evaluation of regional situations as well as offering a sound environmentally-optimal basis for land-use decision-making.

\subsubsection{Assessing Key Regional Natural Resources Vulnerability and Sensitivity-COMPOSITE DRASTIC}

None of the world's nations is sufficiently wealthy to emplace a monitoring network offering on-going, regionwide coverage. Siting must be prioritized. Assessment of relative regional vulnerability can prove a sound basis for this.

Vulnerability assessment of surficial pollutant infiltration through the unsaturated vadose zone to unconfined aquifers below would be best gauged by monitoring quantitative time-of-arrival estimates (Figure 2). Such empirical appraisal, carried out in situ —on the land-at a variety of regional locations, as well as in vitro-in a lab, would ideally assess such infiltration.

There are, however, critical limitations to time-of-arrival models. Hydraulic conductivity of unsaturated zone media for any given topographic slope is a function of lithology and granular particle size (granularity). Granularity can vary considerably within any particular area (Figure 3) [23]. Thus, at this stage in the world's technological development, making accurate quantitative timeof-arrival estimation models for pollutant transport through the unsaturated zone can be unreliable. Furthermore, although percolation through the unsaturated zone-even in porous media - is usually a slow-motion process, there exists a significant hazard that possible "short-cut" phe- 


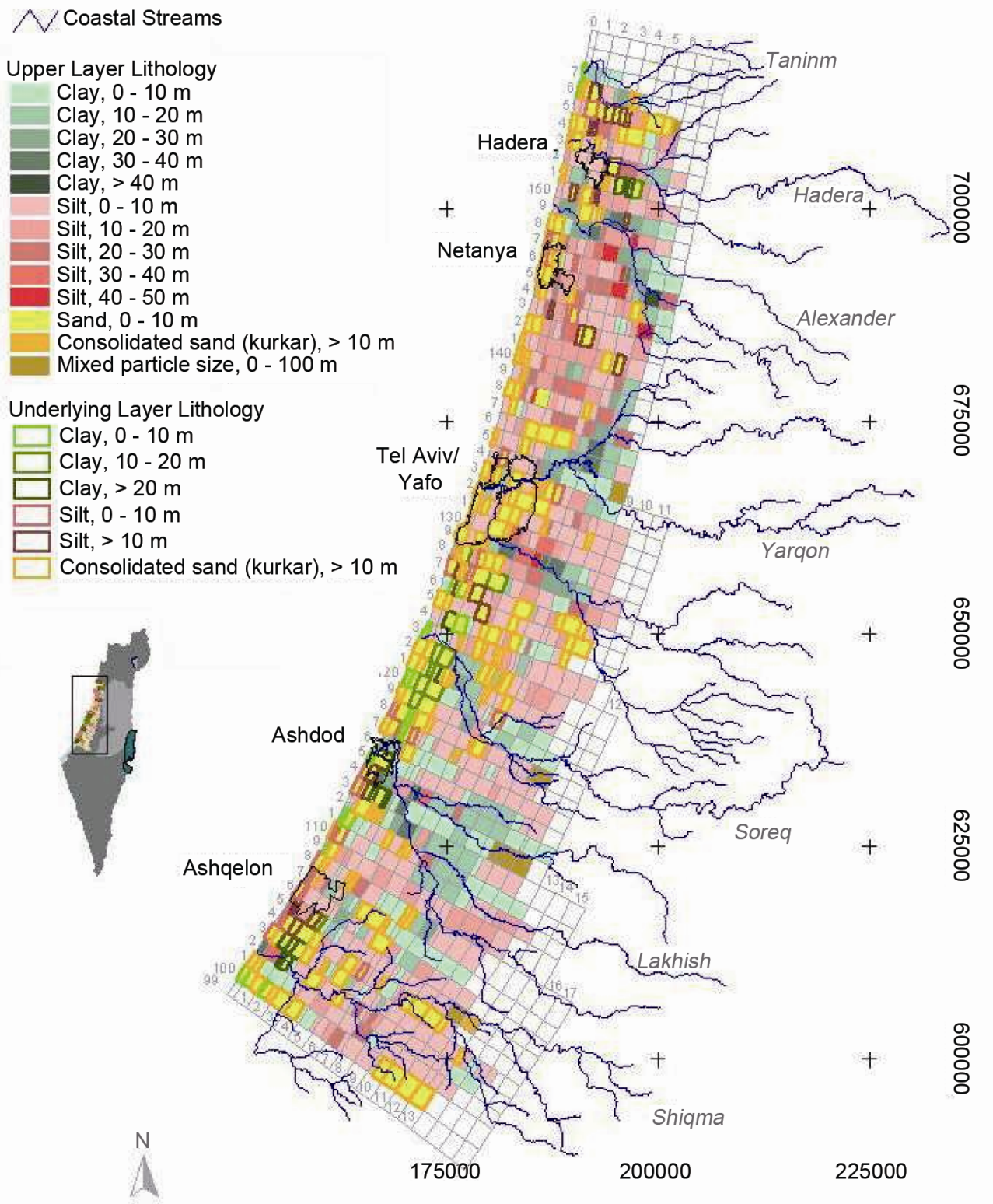

In rate circumstances, we have not depicted the full unsaturated zone lithology due to the existence of greater than two str

Figure 2. Lithological properties of the unsaturated zone of the coastal aquifer of Israel (Melloul, Collin, and Friedman; 2003).

nomena (faulting, etc.) could significantly speed up infiltration (Figure 2) [47,63].

For that reason, qualitative, relative assessment of regional vulnerability must be relied upon to assist in prioritizing decision-making regarding land-use approaches as well as monitoring surveillance efforts. This prioritization can be calibrated by quantitative measurements in the field. Such vulnerability assessment should include all critical assessment parameters, as presented in Figure $2[17,64]$. 


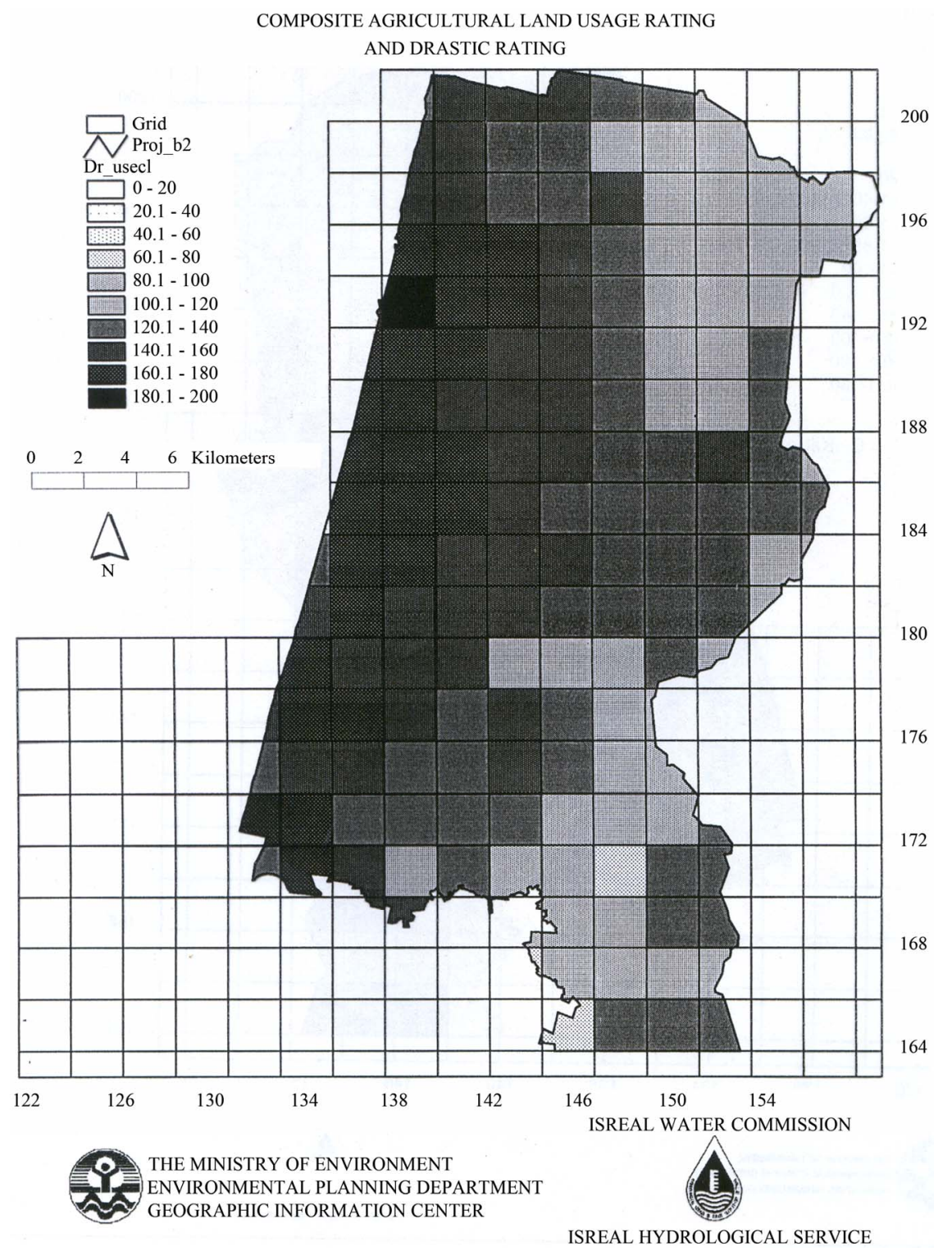

Figure 3. Composite agriculture land usage rating and DRASTIC rating (Secunda, Collin, and Melloul; 1998).

A variation of the U.S. E.P.A.'s DRASTIC model was recently carried out for the unsaturated zone of Israel's Coastal aquifer (Figures 2 and 3) [60,65]. This model's name is an acronym incorporating weighted, additive formulation of seven media parameters: Depth to water

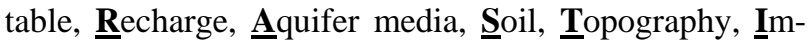
pact of the vadose zone, and hydraulic Conductivity (Figure 3).

Extensive, mainly agricultural, land-use over prolonged periods of time can significantly alter the nature of soil clay populations [35]. To represent such a situation, a "Composite DRASTIC Index" has been employed by the authors to delineate such areas, having increased natural potential vulnerability to groundwater pollution (Figure 3) [60].
This model's calculations are based upon assigned weightings for each selected parameter in order to prioritize potential influence. The "Delphic" process has been utilized to accomplish this, employing judgments of a panel of experts in key related fields regarding potential influence of each parameter upon the regional environment, varying from " 1 "-least influential, to " 10 "most influential, as presented in Table 1. Summation of resultant ratings for each parameter, multiplied by that parameter's weighting, yields relative vulnerability of the regional area.

\subsubsection{Locating and Assessing Potential Regional Pollution Sites-POLLSITE}

In order to establish the present and projected extent of potential pollution across a region's land surface, Israel's 


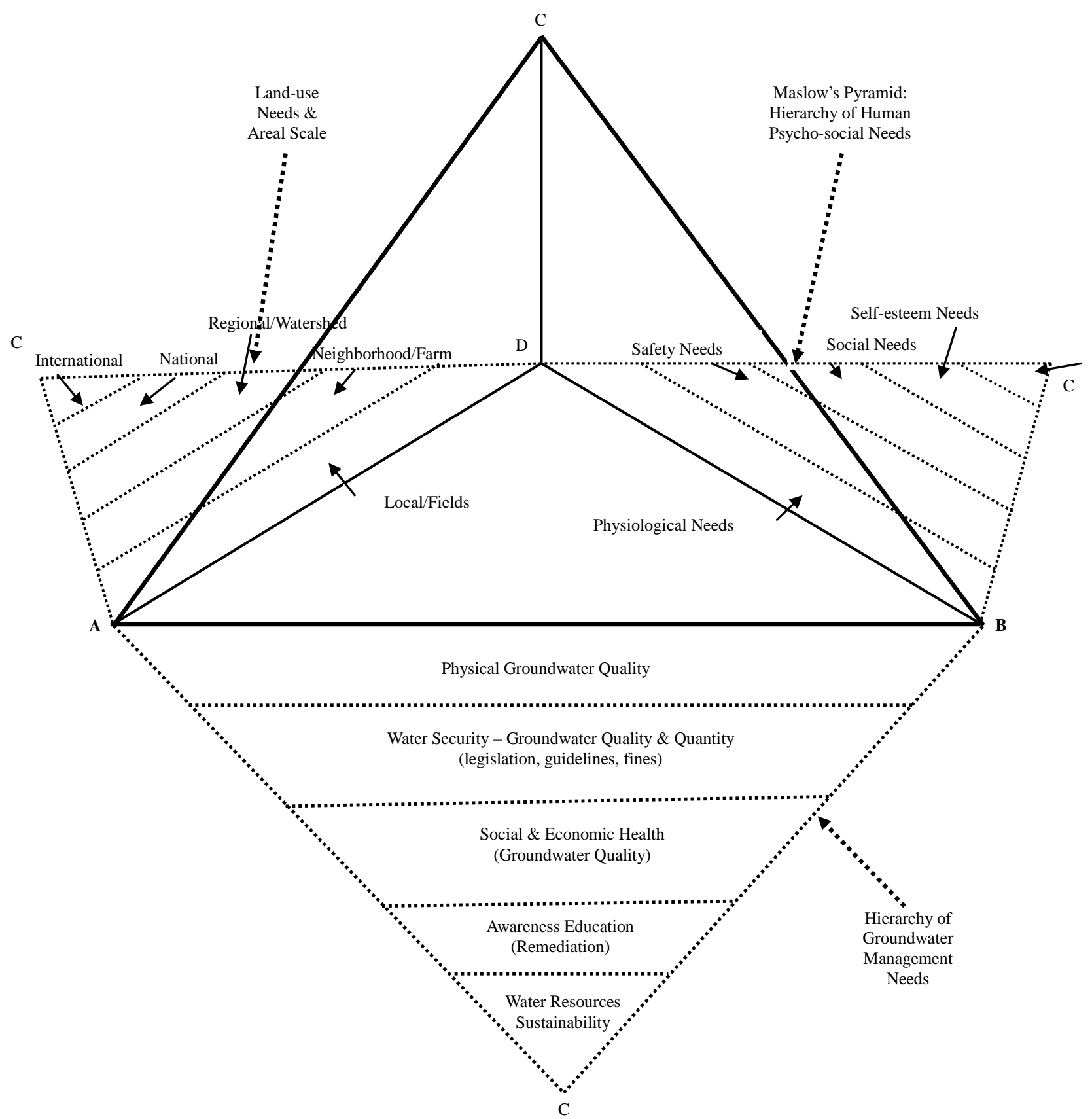

Figure 4. Combined Maslow social pyramid and hydro-environmental pyramids (Melloul and Collin, 2001).

POLLSITE Register of land-use activities has been designed as an interactive data bank registering potentially polluting land-usages. The abbreviation "POLLSITE" stands for "Pollution Site". It assists towards delineating an effective water quality monitoring network, as well as serving as an indicator of the relative vulnerability of water resources. Target sites include toxic, solid, and domestic waste sites; wastewater treatment facilities; effluent reservoirs and fields irrigated with effluents; oil spills and leakages; and industrial operations. A set of indicator pollutants is tied to each land-usage type, and specific fingerprint pollutants are denoted where feasible. These indicators are intended to enable differentiation between potentially polluting sites and neighboring anthropogenic pollution sites with sufficient accuracy as to stand up in court cases [66].

POLLSITE data form the basis for establishing a water quality monitoring network that functions as an earlywarning system to enable immediate remediation efforts at sites in question. The network is intended to facilitate rapid initiative towards preventing or correcting percolation of pollutants from any land-use sites to the underly- 
Table 1. Assessment of weighting of hydro-environmental monitoring parameters (Collin and Melloul, 2008).

\begin{tabular}{|c|c|c|c|c|c|c|c|c|c|c|c|c|}
\hline \multicolumn{2}{|c|}{ Parameters that influence Sea Level Rise (SLR) } & Weighting: & 1 & 2 & 3 & 4 & 5 & 6 & 7 & 8 & 9 & 10 \\
\hline \multicolumn{13}{|c|}{ Natural Parameters } \\
\hline \multicolumn{13}{|c|}{ Tectonic Activities } \\
\hline \multicolumn{13}{|c|}{ Glacial Melting } \\
\hline \multicolumn{13}{|c|}{$\begin{array}{r}\text { Bathymetry (at } 100 \mathrm{~km} \\
\text { from coast) }\end{array}$} \\
\hline \multicolumn{13}{|c|}{$\begin{array}{r}\text { Forest and Vegetative } \\
\text { Cover }\end{array}$} \\
\hline \multicolumn{13}{|c|}{ Solar Influence } \\
\hline \multicolumn{13}{|c|}{ Steric Effect } \\
\hline \multicolumn{13}{|c|}{ Other (please fill in) } \\
\hline \multicolumn{13}{|c|}{ Anthropogenic Parameters } \\
\hline \multicolumn{13}{|c|}{ Total $\mathrm{CO}_{2}$ Emissions } \\
\hline \multicolumn{13}{|c|}{ Population Growth } \\
\hline \multicolumn{13}{|c|}{ Urban Population } \\
\hline \multicolumn{13}{|c|}{$\begin{array}{r}\text { Population Economic } \\
\text { Level (GDP) }\end{array}$} \\
\hline \multicolumn{13}{|c|}{ Deforestation/Forestation } \\
\hline \multicolumn{13}{|c|}{ Global dimming } \\
\hline \multicolumn{13}{|c|}{ Parameters Impacting the Coastal Environment } \\
\hline \multicolumn{2}{|c|}{ Lithology } & & & & & & & & & & & \\
\hline \multirow{2}{*}{ Geomorphology } & Beach Slope & & & & & & & & & & & \\
\hline & Estuaries \& Embayments & & & & & & & & & & & \\
\hline \multirow{2}{*}{ Sea Dynamics } & Tides & & & & & & & & & & & \\
\hline & Waves & & & & & & & & & & & \\
\hline $\begin{array}{r}\text { Coastal } \\
\text { Vegetation }\end{array}$ & $\begin{array}{r}\text { Wetland, Mangrove (etc.) } \\
\text { Buffer }\end{array}$ & & & & & & & & & & & \\
\hline
\end{tabular}

ing phreatic groundwater reservoir. Prioritization is assigned each Register entry, from highest to lowest likelihood of immediate hazard potential to critical water resources.

\subsubsection{Assessing and Siting a Requisite Monitoring Network-MONET}

To enable efficient well siting, Israel has tied its monitoring management to effective regional vulnerability 
assessment. This program is termed "Monet". The abbreviation "MONET" stands for "Monitoring Network". This network emplaces observation meters and wells that enable identification of actual or potential pollutants and their sources. Resultant data chart pathways of pollutant movement, enabling and justifying limitations of natural resource extraction levels. Such a register and its mapping provides the basis for drawing "red lines" as integral parts of effective models that accurately reflect the situations of natural resources systems. Mapping pollutant mitigation routes provides early-warning for pollution incidents or trends, and monitoring system sensitivity to potential environmental stress situations is ensured. Subsequently, both "identify and repair" and "anticipate and prevent" strategies enhance environmental management for satisfactory long-term prospects. Frequency of periodic monitoring assessment is keyed to the degree of data fluctuation involved [42].

\subsection{Land-Use Planning}

\subsubsection{Prioritizing Decision-Making on the Basis of the Composite Maslow Pyramid}

The psychologist Abraham Maslow delineated a hierarchy of human needs (Figure 4) [4]. In the format of a pyramid, he stipulated that until the lowest levels of needs were fulfilled, people would not be ready to deal with higher levels. The base of the pyramid involves such physiological needs as water, oxygen, food, a relatively constant body temperature, and species procreation. Once these needs are fulfilled, the next level of the pyramid involves safety needs: security, stability, law and order. Satisfaction of these concerns enables people to focus upon such social requirements as place in family or community. Only upon realizing these objectives can people go on to meet concerns for esteem, including status and recognition. At the pinnacle of the pyramid lie the needs for self-fulfillment, actualization, understanding, æsthetic appreciation, and spiritual satisfaction (Figure 4) $[61,62,67]$.

In like manner, people's needs for sustainable natural resources and effective environmentally-oriented regional land-use planning begin with personal requirements for self-preservation (Figure 4). A minimal quantity of critically needed natural resources is required before the next concern, maintaining the security of those resources, can be addressed $[43,55,56]$. Once that is adequately satisfied, usage-value from the standpoint of social and economic health of those resources becomes important. Remediation programs and education for public awareness can then augment realization of a pinnacle goal of attaining sustainable on-going development [43]. Local concerns should integrate with neighborhood issues, and be tied in to regional needs and national and international priorities

\section{(Figure 4).}

\subsubsection{Land-Use Planning Based upon Natural Amenities and Constraints}

A productive, cost-effective, and aesthetically pleasing approach towards land-use alteration, as that utilized by the landscape architect Ian McHarg [39], is based upon adjusting long-term regional planning to such key characteristics of the natural environment as its terrain, soils, water, flora, and fauna. This approach utilizes three critical natural parameters affecting regional land-use capabilities: lithology, soil type, and geomorphology. Lithologies can be more or less erodible, depending upon climate. Soil types are clustered into associations according to parent material lithology, permeability, texture, $\mathrm{pH}$, depth to parent material, depth to seasonal water table, presence of clay pans, slope, erodibility, and frequency of flooding $[34,35,68]$. Resultant soil type associations then form a progression from areas presenting minimum problems for intensive land-use alteration to areas where no such alteration should be permitted [51]. Optimal land-use planning would be that which best cooperates with Nature's amenities and constraints by, for instance, enabling major anthropogenic land-use alteration on highlands and plateaus while reserving steeper slopes and flood plains for agriculture, open space, and recreation (Table 2) [38,58].

Certain principles characterize what might be termed "integrative" landscape architecture and regional planning. One encourages and maximizes urban benefits in rural areas and rural benefits in urban areas. An example of such a principle in urban areas encourages residential homes and blocks of flats, commercial centers, and even industrial buildings to gain significant visual appeal and corresponding financial worth by being surrounded by trees and well-planned vegetative cover, a practice long substantiated by real estate agents. Another means of enhancing a healthy and aesthetic urban ambience is "landscape agriculture". Flat urban roofs are a vast source of otherwise wasted real estate, but development of gardens on those roofs, or on unused plots of urban land between buildings, can prove both economical as well as highly attractive. Vegetation on flat roof-tops has the salutary effect of lowering urban temperatures, maximizing rainfall utilization, and providing a soothing natural visual environment for the inhabitants. In the United States, the cities of Chicago and New York have embarked on such development. In Switzerland, all new buildings having flat roofs must incorporate a greenroof concept $[46,69]$. Such roofs must obviously have the requisite carrying-capacity to enable growth of light vegetation in soil or hydroponic containers.

Urban shoreline can and should become a focus for the population's recreational activity, where public access 
Table 2. Land usage categories and intensities for various environmental factors (Collin and Melloul, 2003).

\begin{tabular}{|c|c|c|c|c|c|c|c|c|c|c|c|c|c|}
\hline \multirow{3}{*}{$\begin{array}{l}\text { Environmental } \\
\text { Factor }\end{array}$} & \multirow{3}{*}{\multicolumn{2}{|c|}{ Ranking Criteria }} & \multicolumn{11}{|c|}{ Recommended Land-Use Intensity } \\
\hline & & & \multirow{2}{*}{ Conservation- } & \multicolumn{2}{|c|}{$\begin{array}{c}\text { Military \& } \\
\text { Security }\end{array}$} & \multicolumn{2}{|c|}{ Recreation } & \multicolumn{2}{|c|}{ Agricultural } & \multicolumn{2}{|c|}{$\begin{array}{l}\text { Residential } \\
\text { Settlement }\end{array}$} & \multicolumn{2}{|c|}{$\begin{array}{l}\text { Commercial } \\
\text { \& Industrial }\end{array}$} \\
\hline & & & & $\begin{array}{l}\text { High } \\
\text { Intensity }\end{array}$ & $\begin{array}{l}\text { Low } \\
\text { Intensity }\end{array}$ & $\begin{array}{c}\text { High } \\
\text { Intensity }\end{array}$ & $\begin{array}{c}\text { Low } \\
\text { Intensity }\end{array}$ & $\begin{array}{l}\text { Field } \\
\text { Crops }\end{array}$ & Orchards & $\begin{array}{c}\text { High } \\
\text { Intensity }\end{array}$ & $\begin{array}{c}\text { Low } \\
\text { Intensity }\end{array}$ & $\begin{array}{c}\text { High } \\
\text { Intensity }\end{array}$ & $\begin{array}{l}\text { Low } \\
\text { Intensity }\end{array}$ \\
\hline \multirow{2}{*}{ Physiography } & High Slope & $>20 \%$ & 1 & 1 & 1 & 1 & 1 & 1 & 1 & 1 & 1 & 1 & 1 \\
\hline & Low Slope & $<20 \%$ & 1 & 5 & 2 & 3 & 2 & 4 & 2 & 4 & 3 & 5 & 4 \\
\hline \multirow{6}{*}{ Hydrology } & \multirow{2}{*}{$\begin{array}{l}\text { Water Table } \\
\text { Depth }\end{array}$} & Shallow & 1 & 1 & 1 & 1 & 1 & 1 & 1 & 1 & 1 & 1 & 1 \\
\hline & & Deep & 1 & 5 & 2 & 3 & 2 & 4 & 2 & 4 & 3 & 5 & 4 \\
\hline & \multirow{2}{*}{ Recharge } & High & 1 & 1 & 1 & 1 & 1 & 1 & 1 & 1 & 1 & 1 & 1 \\
\hline & & Low & 1 & 5 & 2 & 3 & 2 & 4 & 2 & 4 & 3 & 5 & 4 \\
\hline & \multirow{2}{*}{$\begin{array}{l}\text { Hydraulic } \\
\text { Conductivity }\end{array}$} & High & 1 & 1 & 1 & 1 & 1 & 1 & 1 & 1 & 1 & 1 & 1 \\
\hline & & Low & 1 & 5 & 2 & 3 & 2 & 4 & 2 & 4 & 3 & 5 & 4 \\
\hline \multirow{2}{*}{ Soils } & Permeable & & 1 & 1 & 1 & 1 & 1 & 1 & 1 & 1 & 1 & 1 & 1 \\
\hline & Impermeable & & 1 & 5 & 2 & 3 & 2 & 4 & 2 & 4 & 3 & 5 & 4 \\
\hline \multirow{4}{*}{ Vegetation } & \multirow{2}{*}{ Tree Cover } & High & 1 & 1 & 1 & 1 & 1 & 1 & 1 & 1 & 1 & 1 & 1 \\
\hline & & Low & 1 & 4 & 2 & 3 & 2 & 4 & 2 & 4 & 3 & 4 & 4 \\
\hline & \multirow{2}{*}{ Other Cover } & High & 1 & 1 & 1 & 1 & 1 & 1 & 1 & 1 & 1 & 1 & 1 \\
\hline & & Low & 1 & 5 & 3 & 3 & 3 & 4 & 3 & 4 & 3 & 5 & 4 \\
\hline
\end{tabular}

Recommended Land-use Intensities for Sustainable Groundwater Resources: 5 = Highest, 4 = High, $3=$ Moderate, 2 = Low, 1 = Lowest.

facilitates enjoyment of its special charms, enhanced by emplacement of hiking and bicycling trails, and contemplation locations along the shore. On the other hand, harbor and power plant facilities, and heavy industry, with its ancillary rail and vehicular service networks, are best be sited in less aesthetically desirable coastal areas. Examples of this are Chicago and the Baltimore Harbor (see 4.2.1 and 4.2.2, below).

\subsection{Utilizing Assessment and Long-Term Planning Tools}

Employment of such assessment approaches as the Composite DRASTIC, POLLSITE, and MONET, along with land-use decision-making based upon natural amenities and constraints (Ian McHarg's approach), prioritized to the needs of the regional population (Composite Maslow Pyramid), could result in a desirable regional situation. Efficient use of such tools could result in cost-effective management of resources.

\section{Exemplary Regional Applications}

Several noted examples of regions around the world have suffered malaise, and overcame this by employing concepts and tools for land-use planning to effectively bridge the gap between malaise and desired regional situations. These regions utilized cost-effective programs that took into consideration the realities of natural resources, fund- ing, and social infrastructure. Such approaches can prove a basis for optimal long-term regional planning recommendations.

\subsection{Historic Anticipation of Ian McHarg's Approach to Land-Use Planning}

Earlier eras have exhibited intuitive employment of measures akin to McHarg's approach towards recognizing and accommodating landscape constraints. For example, past civilizations have been able to extract maximum utilization of minimal regional rainfall. The Nabateans of Israel's Negev region and the Native Americans of the US southwest achieved remarkable balance with harsh, arid environments. Both obtained maximal retention of small rainfall recharge using well-engineered drainage and storage networks tied to drinking water and agricultural irrigation networks. Saving and utilizing each drop of rainfall and dew enabled these cultures to attain optimal agricultural output from minimal rainfall, and thus thrive as societies. Curiously, some two thousand years later, current civilizations throughout the world are just learning to reach the levels of efficiency these cultures had realized in their day [37].

\subsection{Proper Land-Use Planning Vis-à-Vis Environmental Deterioration}

Significant steps have been taken recently around the 
world to harmonize land-use with natural terrain conditions, as well as to assess the relative degree of intolerance of the terrain with regard to proposed land-use alterations. Two examples of such approaches carried out in the United States-in the Chicago and Baltimore regions, are presented here. An exemplary program carried out in the Tel Aviv region of Israel is also noted.

\subsubsection{Chicago's Lake Front Development}

A precursor to McHarg's approach was taken in the early years of the 20th Century, when the city of Chicago embarked upon harmonizing public land-use planning with the amenities of the terrain, based upon suggestions of landscape architect Robert Burnham [49]. As with most cities around the world at the time, Chicago's waterfront had been utilized basically as a loading and unloading area for the raw materials and for industry. Lowest economic and social levels of the population lived near the water. Better-off segments of society concentrated further from the shore. Following Burnham's plan, the city bought up its entire strip of lakefront land, transferred port and industrial activities south of the city, and replaced these with beautiful parkland and open-space, accessible to the public [50]. A landscaped thoroughfare bordered the inland edge of this waterfront park, and the most handsome residential and commercial buildings were erected facing the lakefront across this parkway. Where purchasing and replacing existing critical rail network was excessively costly, the city purchased airrights and built parkland above it [49].

\subsubsection{Baltimore Harbor Renovation}

Land-use decision-making, actually based upon McHarg's approach towards a coastal region's amenities, faced a more difficult challenge than that of Chicago in the city of Baltimore, which borders a labyrinthine harbor embayment rather than the linear Chicago lakefront. As of 1973 , virtually the entire waterfront was inaccessible to the population, functioning as a major port facility and industrial site. In that year, the Baltimore Regional Planning Council reversed the on-going and seemingly inexorable extension of urbanization outwards into the beautiful agricultural and wooded periphery of the city by focusing land-use alteration plans inwards, towards the waterfront. The disparate parties involved in the renovation planning process included local, regional, state, and federal government agencies, private industry, and representatives of ethnic residential neighborhoods adjoining the harbor. A key breakthrough occurred when the Maryland Port Authority requested trading its innercity waterfront for alternative space available along the Chesapeake Bay on the outskirts of the city, to better accommodate the requirements of the recent mode of container, as opposed to previous bulk, shipping. Suc- cessful Inner Harbor development soon afforded the population access to the waterfront and raised water quality of the neighboring Chesapeake Bay. Marinas, museums, parkland, and shopping centers replaced the squalor that had previously typified the port $[59,70,71]$.

The Baltimore Harbor plan was a regional redevelopment project based upon assessment of natural regional amenities and constraints: surface water and floodplains, aquifers and their recharge areas, and terrain-especially steep land, prime agricultural land, forests and woodlands [38]. The project tied these considerations into a demographically and economically integrated regional plan [72].

\subsubsection{Israel's Tel Aviv Metropolitan Region Waterfront Development}

Taking maximal advantage of its beautiful Mediterranean coast near Tel Aviv and Haifa, Israel has begun to utilize patterns similar to those of Chicago and Baltimore. Employing a model similar to that of Chicago, and reflecting the insights of McHarg, public parkland, pedestrian routes, and marinas have been established along the seafront. Such effective use of seafront simultaneously focuses well-planned and socially-useful land-use alteration around this beautiful natural asset, relieving pressure from the few remaining open stretches in the central portion of the country $[12,21,29,71]$.

\subsection{Utilizing DRASTIC, POLLSITE \& MONET for Water Conservation}

Israel has successfully utilized such assessment tools as Composite DRASTIC, along with POLLSITE and MONET, to effectively exploit significant quantities of sewage water to fill the gap in water resource needs. Treatment facilities have been emplaced that convert urban effluents into water that meets Ministry of Health drinking water standards, supplying this water for crop irrigation. Such facilities currently treat effluents of metropolitan Tel Aviv, Jerusalem, Haifa, and the Sharon region. Were urban storm drainage to be integrated with such effluent treatment at these plants, significant savings of water could result [21].

\subsection{Mitigating Soil Degradation While Enhancing Soil Fertility}

Two international approaches dealing with mitigation of soil degradation, maintaining soil fertility, and decelerating the trend towards desertification at regional and local level should be noted [52,72].

In the USA, the Geological Survey urged in 1997 that land subject to desertification be protected or reclaimed by emplacement of straw grids, to decrease vulnerability to surface wind. Shrubs and trees planted within the grids 
would be protected by the straw until they took root. Shrubs planted on the lower third of a dune's windward side would stabilize the dune, preventing much of the sand from moving. Dune tops would be protected by planting trees. Oases and farmlands in windy regions would be protected by planting tree fences, hedges, or grass belts [37].

China has implemented an elaborate network of shelterbelts and forestry plantations, "The Great Green Wall”, across northern China, as part of the "Three-North Shelterbelt Program” (TNSP). Its objective is to protect agricultural and pastoral lands as well as human settlements from wind and water erosion. The program proposes reforestation and re-vegetation of 4.06 million $\mathrm{km}^{2}$ (1.33 million $\mathrm{km}^{2}$ of desert lands) $-42 \%$ of the country. This Green Wall is planned to eventually stretch more than $5700 \mathrm{kms}$. in length, far longer than the famous Great Wall, and is intended to protect sandy, desert lands understood to have been created by human activity. The TNSP objectives are to improve soil and water conservation, moderating the effect of strong winds and desertification through increased forest and vegetative cover. An estimated 20 million ha $\left(0.2\right.$ million $\left.\mathrm{km}^{2}\right)$ have already been established under the TNSP through planting or aerial seeding [37].

Long-term land-use decision-making can thus be based upon a landscape's constraints and amenities, as in McHarg's approach. A prioritized staging of these steps can utilize a Maslow-type pyramid of the society's needs for management of natural resource sustainability and effective utilization. And integrating decision-making to relative vulnerability, utilizing a DRASTIC-type model, could yield successful solutions to critical regional environmental challenges.

\section{Recommended Guidelines}

The following guidelines and operational measures for sustainable coastal land-use planning and natural resources management are recommended to close or mitigate the gap between the present malaise and a desirable, environmentally-optimal situation.

\subsection{Assessment of Sensitivity and Vulnerability of Regional Natural Resources to Pollution}

1) Register and map in a POLLSITE-type format (§3.1.2) all key regional land-use sites,, along with any and all potential pollutants emitted from those sites, which might threaten regional natural resources.

2) Employ a form of composite DRASTIC model (§3.1.1) as an indirect, qualitative means towards regionally estimating and mapping relative vulnerability of that resource to each potential pollutant threat.

3) Utilize such means as the Delphic Method (§3.1.1) to determine, weigh, and map all natural and anthropogenic parameters that might subject each resource to the relative threat of potential pollutants, as shown in Table 1.

4) Calibrate indirect, qualitative vulnerability assessments to regional natural resources, utilizing in situ, quantitative assessments at key sites with appropriate frequency.

5) List "indicator and fingerprint pollutants" that might be employed towards specifically identifying land-use sources, and map their regional occurrence.

\subsection{Planning, Delineation, and Prioritization of Monitoring Networks}

Effective and optimized monitoring networks should be planned on the basis of a register and map of key regional pollution sites, including indicator and fingerprint pollutants, to enable a prioritized MONET-type network of observation monitors (\$3.1.3).

1) Site such monitoring so as to chart pathways of pollutant movement as well as to enable and justify effective mitigation measures.

2) Determine monitoring frequency on the basis of the data fluctuation involved.

3) Employ accurate cost-benefit analysis as the basis for decision-making when delineating monitoring networks and siting.

\subsection{Land-Use Planning Tied to Natural Amenities and Constraints}

1) Maximize rural amenities in urban areas and urban amenities in rural areas.

2) Utilize floodplains solely for recreation, agriculture, and open space.

3) Sequester shorelines for public access, as urban "front yards".

4) Utilize flat city roofs as well as unused plots of land for development of urban gardens.

5) Improve coastal stability, especially in coastlines composed of highly erodible lithology, by utilizing natural protective coastal vegetation as a buffer to dissipate climatic extremes of shoreline weather (hurricanes) and other natural extreme events (tsunamis).

6) Optimize water use by reclamation and mitigation of water losses.

\subsection{Coordinating Land-Use Planning Decision-Making with Societal Needs}

1) Prioritize land-use planning by sequencing decision-making upon a Maslow-type pyramid (§3.2.1) to effectively tie in land-use alteration benefits on a stepby-step basis to fulfill the full range of a region's human 
and environmental needs, from the most basic to the furthest advanced.

2) Effectively educate the public towards awareness of ecological concerns, sustainable environmental needs, as well as capabilities for citizen input to public environmental and resource management decision-making, in order to enlist public support for costly environmental management and remediation measures having optimal priority.

3) Strengthen effective legislation and judicial means for implementing key operational measures for sustainable environmental management, imposing significant fines as well as payment of costs for damages and cleanup upon violators of environmental regulations and guidelines.

\section{REFERENCES}

[1] Anonym, “Tapping the Oceans," The Economist, Vol. 387, No. 8583, 2008, pp. 18-20.

[2] E. Kolbert, “Outlook-Extreme (Changing Rains)," National Geographic Magazine, Vol. 215, No. 4, 2009, pp. 60-65.

[3] A. J. Melloul, "Sea Water Rise and Its Impact on the Israel Coastal Aquifer," Agamit Water in our Country Journal, Vol. 168, 2004, pp. 6-8.

[4] D. S. Rosen, "Long-Term Remedial Measures of Sedimentological Impact Due to Coastal Developments on the Southeastern Mediterranean Coast," Proceedings of Littoral the Changing Coast Eurocoast, Vol. 2, No. 40, 2002, pp. 322-331.

[5] A. J. Melloul and M. L. Collin, "Seawater Rise and Its Adverse Input on Stressed Coastal Aquifers and Their Groundwater Reserves,” Institute Technology Press, 2005, pp. 184-192.

[6] S. Rahmstorf, “A Semi-Empirical Approach to Projecting Future Sea-Level Rise,” Science, Vol. 315, No. 5810, 2006, pp. 368-370. doi:10.1126/science.1135456

[7] G. W. Huber and B. E. Dale, "Grassoline at the Pump," Scientific American Magazine, Vol. 301, No. 1, 2009, pp. 40-47. doi:10.1038/scientificamerican0709-52

[8] G. McBean, A. Weaver and R. Nigel, "The Science of Climatic Changes: Where We Are in Our Knowledge," Vol. 2, No. 4, 2001.

[9] P. Miller, "Saving Energy Starts at Home," National Geographic Magazine, Vol. 215, No. 34, 2009, pp. 60-81.

[10] G. Stix, et al., "Energy's Future-Beyond Carbon,” Scientific American Magazine, Vol. 295, No. 3, 2006, pp. 1-94.

[11] C. A. Cabanes and C. Le Provost, "Sea Level Rise during Past 40 Years Determined from Satellites and in Situ Observations,” Science, Vol. 294, 2001, pp. 840-842.

[12] Society of Nature Protection and the Coast, "Coasts of Israel, Sea Level Rise and the Situation of Mediterranean Sea Coasts,” Report No. 5, 2004.

[13] V. Gornitz, “Global Coastal Hazards from Future Sea
Level Rise,” Paleogeography, Paleoclimatelogy, Paleoecology, Global and Planetary Change, Elsevier Science Vol. 89, No. 4, 1991, pp. 379-398.

[14] B. McKibben, “Carbon's New Math: To Deal with Global Warming, the First Step Is to Do the Numbers," National Geographic Magazine, 2007, pp. 33-37.

[15] A. Pinhas. K. Pavel, J. K. Yoram and R. Schwarzbard, "Global Dimming or Local Dimming Effect of Urbanization on Sunlight,” Geophysical Research Letters, Vol. 32, 2005.

[16] I. Porat, "Influence of Sea Level Rise on Israel's Coastal Aquifer,” Report 1, 2004, pp. 35-40.

[17] L. J. Andersen and E. Gosk, “Applicability of Vulnerability Maps," Environmental Geology and Water Sciences, Vol. 13, No. 1, 1989, pp. 39-43. doi:10.1007/BF01666570

[18] S. Appleyard, “The Impact of Urban Development on Recharge and Groundwater Quality in Coastal Aquifer in Perth, Western Australia,” Hydrogeology Journal, Vol. 3, No. 2, 1995, pp. 65-75. doi:10.1007/s100400050072

[19] T. Appenzeller, "Big Thaw," National Geographic Magazine, Vol. 213, No. 6, 2007, pp. 56-71.

[20] J. Forkasiewickz and J. Margat, "L'exploitation des Rserves d'eau Souterraine en Zones Aride Etemi Aride: Essai de Synthese,” Bulletin du BRGM, Vol. III, No. 2, 1982, pp. 115-126.

[21] Israel Hydrological Service Report, "Development of Groundwater Resources in Israel up to Autumn 2002,” Israel Hydrological Service, Jerusalem, 2003.

[22] IMH, “Drinking Water Standards,” Israel Ministry of Health Report, 1994.

[23] A. J. Melloul and L. C. Goldenberg, "Groundwater Pollution by Airborne Toxic Contaminants: A Factor to be Considered in Groundwater Management," Groundwater Quality Management, No. 220, 1994, pp. 95-105.

[24] A. J. Melloul and M. L. Collin, "The Hydrological Malaise of the Gaza Strip,” Journal of Earth Sciences, Vol. 43, 1994, pp. 105-116.

[25] A. J. Melloul and L. C. Goldenberg, "Monitoring of Seawater Intrusion in Coastal Aquifers: Basics and Local Concerns,” Journal of Environmental Management, Vol. 51, 1997, pp. 73-86. doi:10.1006/jema.1997.0136

[26] A. J. Melloul and D. G. Zeitoun, ”A Semi-Empirical Approach to Seawater Intrusion Monitoring in Israel's Coastal Aquifer,” In: J. Bear, A. H.-D. Cheng, S. Sorek, D. Ouazar and I. Herrera, Eds., Theory and Applications of Transport in Porous Media: Seawater Intrusion in Coastal Aquifers-Concepts, Methods and Practices, 1999, pp. 543-557.

[27] US Environmental Protection Agency, "DRASTIC: A Standard System for Evaluating Groundwater Potential Using Hydrogeological Settings,” NWWA/EPA Series, Ada, 1985.

[28] L. C. Goldenberg and A. Melloul, "Hydrological and Chemical Management of an Aquifer,” Journal of Environmental Management, Vol. 42, 1994, pp. 247-260. doi:10.1006/jema.1994.1071 
[29] Y. Tolmach, "Hydrogeological Atlas of Israel, Coastal Aquifer, Areas of Tel Aviv through Hadera,” Hydrological Service Report, Jerusalem, 1979.

[30] R. Draper, “Australia’s Dry Run,” National Geographic Magazine, Vol. 215, No. 4, 2009, pp. 34-59.

[31] K. Warne, "Forests of the Tide (Mangroves)," National Geographic Magazine, Vol. 211, No. 2, 2007, pp. 132151.

[32] L. Muszkat, E. Rosenthal, D. Ronen and M. Margaritz, "Organic Contaminants in the Israeli Coastal Aquifer," Environmental Quality and Ecosystem Stability," Proceedings of 4th International Conference of the Israel Society for Ecology and Environmental Quality Sciences, Vol. IV-A, Jerusalem, 1989, pp. 471-477.

[33] D. A. Vaccari, "Phosphorus-A Looming Crisis," Scientific American Magazine, Vol. 300, No. 6, 2009, pp. 4247.

[34] N. C. Brady and R. R. Weil, "The Nature and Properties of Soil,” 11th Edition, Prentice Hall, 1996.

[35] M. L. Collin and J. Dan, "Degradation of Mont- morillonite Clays Owing to Prolonged On-Going Growth of Agricultural Cotton in the Binyamina Region of Israel," Journal of Geological and Agronomical Ecology, Vol. 8, No. 4, 1986, pp. 218-231.

[36] Glossary of Soil Science Terms, SSSA, 1970.

[37] C. C. Mann, "Our Good Earth-Soils, Terra Preta do Indio,” National Geographic Magazine, Vol. 214, No. 9, 2008, pp. 92-93.

[38] I. L. McHarg, "Design with Nature," Doubleday, New York, 1969.

[39] C. C. Travi and A. Doty, "Can Contaminated Aquifers at Superfund Sites Be Remediated?” Environmental Science \& Technology, Vol. 24, No. 10, 1990, pp. 1464-1466. doi:10.1021/es00080a600

[40] L. Wingo, "Cities and Space: The Future Use of Urban Land,” Johns Hopkins Press, Baltimore, 1975.

[41] E. Zwingle, "MegaCities-Challenges for Humanity," National Geographic Magazine, November 2002.

[42] M. L. Collin and G. Eitan, "The MONET Register of Monitoring Sites,” Israel Hydrological Service, Jerusalem, Vol. 1, No. 99, 1999.

[43] A. J. Melloul and M. L. Collin, “A Hierarchy of GroundWater Management, Land-Use, and Social Needs Integrated for Sustainable Resource Development," Environment, Development and Sustainability Journal, Vol. 3, 2001, pp. 45-59. doi:10.1023/A:1011420206575

[44] J. G. Mitchell, “Our Polluted Runoff,” National Geographic Magazine, Vol. 189, No. 2, 1996, pp. 106-125.

[45] A. J. Melloul and L. C. Goldenberg, "The Rainy Winter of 1991/92 and Its Influence on the Groundwater Quality in the Coastal Plain Aquifer of Israel," Water and Irrigation Journal, Vol. 319, 1993, pp. 51-54.

[46] V. Klinkenborg, "Up on the Roof (Roof Gardens)," National Geographic Magazine, Vol. 215, No. 5, 2009, pp. 84-104.

[47] U. Zoller, L. C. Goldenberg and A. J. Melloul, "The
Short-Cut Enhanced Contamination of the Gaza Strip Coastal Aquifer,” Water Research Journal, Vol. 32, 1998, pp. 1779-1788. doi:10.1016/S0043-1354(97)00395-3

[48] A. J. Melloul and S. H. Wollman, "Qualitative Hydrological and Land-Use Planning Tools for the Israel Coastal Aquifer," Science of the Total Environment, Vol. 309, No. 3, 2009, pp. 1-17. doi:10.1016/S0048-9697(03)00004-4

[49] D. H. Burnham and E. H. Bennett, "Plan of Chicago," Princeton Architectural Press, 1993.

[50] City of Chicago, JJR Landscape Architecture, "Chicago Lakefront Harbor Framework Plan,” 2007.

[51] M. L. Collin, “Natural Criteria for Land-Use,” Baltimore Regional Planning Council, State of Maryland, 1973.

[52] J. Albaladejo, M. Martinez-Mena, A. Roldan and V. Castillo, "Soil Degradation and Desertification Induced by Vegetation Removal in a Semi Arid Environment," Soil Use and Management, Vol. 14, No. 1, 1998, pp. 1-5. doi:10.1111/j.1475-2743.1998.tb00602.x

[53] R. Lal, "Deforestation and Land-use Effects on Soil Degradation and Rehabilitation in Western Nigeria; Runoff Soil Erosion and Nutrient Loss," Land Degradation \& Development, Vol. 7, No. 2, 1996, pp. 99-110. doi:10.1002/(SICI)1099-145X(199606)7:2<99::AID-LD $\underline{\text { R220>3.0.CO;2-F }}$

[54] Y. Bachmat and M. L. Collin, "Management-Oriented Assessment of Groundwater Vulnerability to Pollution," Israel Hydrological Service Report, Jerusalem, 1990.

[55] J. N. Pretty, "Sustainability Works," Our Planet, Vol. 8, No. 4, 1996, pp. 19-22.

[56] G. A. Schultz and M. Hornbogen, "Sustainable Development of Water Resources Systems with Regard to Longterm Changes of Design Variables, Modeling and Management of Sustainable Basin-Scale Water Resource Systems," Proceedings of Boulder Symposium, IAHS, Vol. 231, 1995, pp. 31-40.

[57] Solid Earth Science Working Group, "What Are the Interactions Among Ice Masses, Oceans, and the Solid Earth and Their Implications for Sea-Level Changes?” Solid Earth Science Working Group, 2003.

[58] C. Morris, "The Rights and Duties of Beasts and Trees: A Law Teacher's Essay for Landscape Architects,” Journal of Legal Education, Vol. 17, 1964, pp. 186-192

[59] M. L. Collin, “An Evaluation of Baltimore Harbor Landuse Potentials,” Baltimore Regional Planning Council, Baltimore, 1973.

[60] S. Secunda, M. L. Collin and A. J. Melloul, "Groundwater Vulnerability Assessment Using a Composite Model Combining DRASTIC with Extensive Agricultural Landuse in Israel's Sharon Region,” Journal of Environmental Management, Vol. 54, 1998, pp. 131-142.

[61] A. Maslow, "The Comparative Approach to Social Behavior,” Journal of Social Forces, Vol. 15, 1937, pp. 487490. doi:10.2307/2571416

[62] A. Maslow, “A Theory of Human Motivation,” Psychological Review, Vol. 50, 1943, pp. 370-396. doi:10.1037/h0054346 
[63] L. C. Goldenberg, A. Melloul and U. Zoller, "The 'Short-Cut' Approach for the Reality of Enhanced Groundwater Contamination,” Journal of Environmental Management, Vol. 46, 1996, pp. 311-326. doi:10.1006/jema.1996.0024

[64] W. Cramer and J. Vrba, "Vulnerability Mapping: Proceedings of the International Conference on Vulnerability of Soil and Groundwater to Pollutants,” The Hague, 1987, pp. 45-48.

[65] L. Aller, J. H. Bennet, H. Lehr and R. J. Petty, “DRASTIC: A Standardized System for Evaluating Groundwater Potential Using Hydrogeological Settings,” EPA/600/285/018/R.S, Kerr Environmental Research Laboratory, US Environmental Protection Agency, Ada, 1985.

[66] M. L. Collin, “POLLSITE Land-Use Register,” Hydrological Report, Israel Hydrological Service, Jerusalem,
Vol. 2, No. 95, 1995.

[67] L. R. Brown, "Could Food Shortages Bring down Civilization?” Scientific American Magazine, Vol. 300, No. 5, 2009, pp. 40-47. doi:10.1038/scientificamerican0509-50

[68] P. Brunn, "Review of Conditions for Uses of the Brunn Rule of Erosion,” Coastal Engineering, Vol. 7, 1983, pp. 77-89. doi:10.1016/0378-3839(83)90028-5

[69] M. J. Heckenberger, “Garden Cities,” Scientific American Magazine, Vol. 301, No. 4, 2009.

[70] M. L. Collin, “The Baltimore Harbor Plan,” Baltimore Regional Planning Council, Baltimore, 1975.

[71] Wallace-McHarg Associates, "Plan for the Valleys," Philadelphia, 1963.

[72] P. Leyhausen, "The Sane Community-A Density Problem?” Discovery, 1965, pp. 34-48. 